\title{
The unusual inter-tidal niche of the rare moss Bryum marratii
}

Des A. Callaghan ${ }^{1}$, Gareth Farr ${ }^{2}$

${ }^{1}$ Bryophyte Surveys Ltd, Stroud, UK, ${ }^{2}$ British Geological Survey, Cardiff, UK

Correspondence to: Des A. Callaghan, 65 Belle Vue Road, Stroud, Gloucestershire, UK. E-mail: des.callaghan@bryophytesurveys.co.uk

\begin{abstract}
This is the first detailed ecological investigation of the rare moss Bryum marratii. Results show occupancy of a niche at the two study sites that is unusual amongst bryophytes, within the upper edge of saltmarsh. All colonies ( $n=120)$, which comprise the largest populations in Wales, occur in an elevation zone of just $57 \mathrm{~cm}$ and are subject to frequent inundation by higher spring tides. In total, the average location of a B. marratii colony was submerged by seawater 3.6 day $^{-1} \mathrm{yr}^{-1}$. Sea level rise, projected in the study region to be $30-46 \mathrm{~cm}$ during the current century, is a major threat to the long-term survival of these populations.
\end{abstract}

\section{Keywords:}

Spring tides, saltmarsh, sea level rise, salt tolerance

\section{Introduction}

Bryum marratii Wilson (Bryophyta: Bryaceae) is a moss of high conservation concern in Britain, listed as 'Vulnerable’ on the UK Red Data List (Hodgetts, 2011), 'Endangered' on the Welsh Red Data List (Bosanquet \& Dines, 2011) and considered to be of principal importance for conservation under Section 7 of The Environment (Wales) Act 2016. It is categorised as 'nationally rare' (Pescott, 2016) and was recorded from only 1110 x 10 km Ordnance Survey grid cells during 19902013 (Blockeel et al., 2014). Elsewhere in Europe, the species is generally rare, being a candidate for inclusion in the forthcoming European Red Data List and known mainly from north-western countries: Denmark, Estonia (Vulnerable), Finland (Endangered), France, Germany (Critically Endangered), Iceland, Ireland, Latvia, The Netherlands (Vulnerable), Northern Ireland (Extinct), Norway (Near-threatened), Poland (Extinct), Slovakia (Critically Endangered) and Sweden (Nearthreatened) (Lockhart et al., 2012; Hodgetts, 2015; N.G. Hodgetts, pers. comm.). Outside Europe, it is reported only from the Altai Mountains (north-central Asia) and very locally in North America, plus an unusual occurrence in Yemen (Lockhart et al., 2012). 
The complex ability to endure salt concentrations approaching those of seawater is an unusual trait amongst land plants (Flowers et al., 2010). This is reflected by habitat occupancy amongst bryophytes, whereby saltmarsh is a normal habitat for only 14 (1.3\%) species in Britain and Ireland (Hill et al., 2007), amongst them Bryum marratii. Perhaps because large parts of saltmarshes usually lack any bryophytes, this habitat has been ignored by bryologists, with very few published studies (Adam, 1976; Garbary et al., 2008; Zechmeister, 2005). Likewise, the ecology of B. marratii is virtually unstudied, the very brief examination of habitat occupied at an inland saltmarsh in Slovakia (Šoltés et al., 2010) perhaps based on a blunt-leaved form of B. pseudotriquetrum (formerly known as B. neodamense). Given the species is of conservation concern, it is important to gain a better understanding of its habitat requirements. The purpose of the present study is to provide such, specifically regarding the tidal characteristics of occupied locations.

\section{Materials and Methods}

\section{Study sites}

The study sites comprise two coastal saltmarshes in Carmarthen Bay, South Wales (Figure 1), at Pembrey Burrows (514'01.8" N, 4²0'18.9" W) and Whiteford Burrows (51³7'48.6" N, $4^{\circ} 14^{\prime} 46.3^{\prime \prime} \mathrm{W}$ ). The climate is oceanic, with 150 rain-days $\mathrm{yr}^{-1}$ (days with $>1 \mathrm{~mm}$ rain) and average temperatures of $15.7^{\circ} \mathrm{C}$ during the hottest month (July) and $5.0^{\circ} \mathrm{C}$ during the coldest month (February) for the period 1961-2002 (Met Office data supplied through the UK Climate Impact Programme). Both saltmarshes are within riverine estuaries and have developed behind sand dune spits, which provide shelter from the open sea. The site at Pembrey is within Pembrey Coast Site of Special Scientific Interest (SSSI), and that at Whiteford is within Whiteford Burrows, Landimore Marsh and Broughton Bay SSSI and Whiteford National Nature Reserve (NNR). Both are within Carmarthen Bay and Estuaries Special Area of Conservation (SAC). These two saltmarshes support the largest populations of Bryum marratii in Wales, possibly in Britain. The moss was first found at Pembrey in April 2013 (Bosanquet, 2013) and at Whiteford in April 2012 (Bosanquet, 2012).

\section{Locations of Bryum marratii colonies}

A detailed search for colonies of Bryum marratii was undertaken on 30 April 2017 (Pembrey) and 1 May 2017 (Whiteford). Once found, the location (x-, y- and z-coordinates) of each colony was recorded with a Leica Viva GS14 GPS (Leica Geosystems, Heerbrugg, Switzerland). The general distribution pattern of colonies at both sites had not changed significantly from that reported and photographed by Bosanquet (2012, 2013).

\section{Tidal inundation}


The nearest tide gauge to the study sites is the British Oceanographic Data Centre (BODC) gauge at The Mumbles (5134'12.0" N, 358'31.6" W), located in nearby Swansea Bay (Figure 1). Tide level data from this gauge, logged every 15 mins, was accessed for 1 January 2010 to 9 June 2014. The initial dataset included 155,591 measurements, from which 35,112 (23\%) were excluded because they were marked as 'improbable' by quality control at BODC. The final dataset of 120,484 values was used to provide estimates of the frequency, duration and timing of tidal inundation events at locations occupied by B. marratii colonies. Inundation of the lowest colony of B. marratii at Whiteford Burrows was observed in the field during a high spring tide on the morning of 26 May 2017, when a sample of water that covered the colony was collected. The water sample was stored in a freezer before being transported to a laboratory where $\mathrm{pH}$ and electric conductivity (EC) were measured, the former with a Thermo Orion 720A probe (Thermo Fisher Scientific, Waltham, USA) and the latter with a Mettler Toledo SevenMulti instrument (Mettler Toledo, Zaventem, Belgium), according to United Kingdom Accreditation Service (UKAS) standards.

\section{Data analysis}

Statistical analyses were undertaken in R (R Core Team, 2017). A Welch Two Sample t-test was conducted to compare elevation of colonies between the two study sites. Spatial analyses and mapping were undertaken in Quantum GIS (Quantum GIS Development Team, 2017).

\section{Results}

\section{Locations of Bryum marratii colonies}

A total of 120 colonies of Bryum marratii were found, 76 along $234 \mathrm{~m}$ of upper saltmarsh at Pembrey and 44 along $680 \mathrm{~m}$ of upper saltmarsh at Whiteford (Figure 2). Each colony comprised a small tuft of erect shoots, 1-5 cm diameter. Sporophytes were not seen, but deciduous shoot tips were frequent. Location coordinates of colonies (Appendix 1) had a mean horizontal accuracy of $0.78 \mathrm{~cm}$ (range $=0.50-6.2 \mathrm{~cm}$ ) and a mean vertical accuracy of $1.2 \mathrm{~cm}$ (range $=0.8-3.2 \mathrm{~cm})$. Of 75 occupied OS 1 x 1 m grid cells, the majority ( $n=52$; 69\%) contained only a single colony (Figure 3). The largest cluster of colonies was at Pembrey (Figure 4), where up to six colonies were present in a single OS 1 x $1 \mathrm{~m}$ grid cell. There was a small but significant difference in the elevation of $B$. marratii colonies between sites, those at Pembrey ( $\bar{x}=4.70$ maOD, s.d. $=0.056, n=76)$ on average 7.1 cm lower than those at Whiteford $(\bar{x}=4.77$ maOD, s.d. $=0.082, n=44) ; t(66.95)=-5.06, p=<0.01$. Across the two sites, all colonies ( $n=120)$ occur in an elevation range of 0.57 m (4.42-4.99 maOD), reduced to just $0.32 \mathrm{~m}$ when the two most extreme outliers are omitted (4.56-4.88 maOD; $n=118$ ).

\section{Tidal inundation}


Tide levels ranged across 10.61 m (-4.88-5.73 maOD) within the study areas. All Bryum marratii colonies are within this inter-tidal zone, limited to a narrow upper part. Here, they are inundated many times, 32-128 events $\mathrm{yr}^{-1}$, during 'spring tides', when tidal bulges formed by the sun and moon coincide to produce the highest tides (Table 1; Figure 5). Spring tides are clustered around two periods each month, during 'new moon' and 'full moon' lunar phases, though not all produce inundation events; of the 88 studied, 59 (67\%) produced tides high enough to submerge, at least, the lowest B. marratii location (Figure 5). The site of the lowest colony experienced the longest tidal inundation event, 3 hr 15 min, on 3 January 2014, when water depth reached $131 \mathrm{~cm}$. On average, each location of a B. marratii colony was submerged 3.6 day $^{-1} \mathrm{yr}^{-1}$ (range $=1.3-8.1$ ). Water that inundated the lowest colony at Whiteford on 26 May 2017 had pH $=7.41$ and EC $=5.44 \mathrm{~S} / \mathrm{m}$ (at 25 $\left.{ }^{\circ} \mathrm{C}\right)$.

\section{Discussion}

This is the first detailed study of any aspect of the ecology of the rare moss Bryum marratii. Results show occupancy of a niche at the study sites which is unusual amongst bryophytes, at the upper edge of saltmarsh. All colonies of the moss, which comprise the largest populations in Wales, are subject to frequent inundation by higher spring tides, within a very narrow elevation zone, just 57 cm. EC of water that inundated the lowest colony at Whiteford on 26 May 2017 is typical of surface seawater in the region of the British Isles (Tyler et al., 2017), suggesting salinity was not substantially reduced by local freshwater inputs. However, further data on water salinity during inundation events are desirable, including direct measures of salinity. Very few other bryophytes occur close to the moss, limited to occasional small patches of Didymodon tophaceus and Hennediella heimii. Above the B. marratii zone, extensive mats of the large pleurocarpous moss Calliergonella cuspidata become dominant, where absence of the smaller moss may be due primarily to competitive exclusion. Below the B. marratii zone, limited tolerance of tidal inundation could explain its absence.

Observations in Britain and Ireland suggest Bryum marratii is often associated with freshwater flushing onto upper saltmarshes (Bosanquet, 2012, 2013; Lockhart et al., 2012; Blockeel et al., 2014). The habitat of the moss at Whiteford lies adjacent to a dune aquifer, a simple groundwater dome created by direct rainfall recharge, which discharges onto the upper saltmarsh (Stratford et al., 2012). The saltmarsh at Pembrey likewise borders a dune aquifer that discharges onto the marsh. At the time of the present fieldwork, visible surface water seepages from the aquifers were very localised and whilst some colonies of $B$. marratii grew along such flushes, most colonies were not 
clearly associated with aquifer discharge. However, diffuse discharge, which may not become visible as seepage lines, could be important.

Areas of saltmarsh occupied by Bryum marratii at Pembrey and Whiteford are heavily grazed by cattle and ponies, respectively. Grazing appears to be important for creating open patches of soil that may be colonised by the moss and for preventing competitive exclusion by larger species. Indeed, the species appears to have been lost from its only locality in Northern Ireland because of cessation of grazing at saltmarsh edges, and lack of grazing leading to dense grass cover along upper saltmarsh currently threatens several other Irish populations (Lockhart et al., 2012). Similarly, at Morfa Harlech, Wales, where grazing by cattle is relatively light, colonies of $B$. marratii discovered in September 2015, which had colonised soil exposed along wheel ruts through a foredune slack (Holyoak, 2015), were all lost by November 2017 due to competitive exclusion by the mat-forming grass Agrostis stolonifera L. (Callaghan, 2017).

Whilst this work provides important new insights into the niche occupied by Bryum marratii, further study is clearly required, to gain a better understanding of its habitat requirements and conservation needs. This is especially important when considering sea level rise, projected in the region to be 30-46 cm during the current century (Lowe et al., 2009) and presenting a major risk to the long-term survival of the populations investigated.

\section{Acknowledgements}

Funding for this work was provided by WREN. Many thanks to Colin Cheesman (Plantlife) for handling the research contract and to the landowners, The National Trust and Ministry of Defence, for site access permissions. Various help and information was provided by Sam Bosanquet (Natural Resources Wales), Tom Kelly (British Geological Survey), Nick Hodgetts, David Holyoak and Barry Stewart. Gareth Farr publishes with the permission of the executive director, British Geological Survey (Natural Environment Research Council). This study uses data from The Mumbles tidal gauge, provided by the British Oceanographic Data Centre. Thanks also to two anonymous referees for their helpful comments.

\section{ORCID}

Des Callaghan https://orcid.org/0000-0002-0415-1493

Taxonomic Additions and Changes: Nil.

\section{References}


Adam, P. 1976. The occurrence of bryophytes on British saltmarshes. Journal of Bryology, 9: 265274.

Blockeel, T.L., Bosanquet, S.D.S., Hill, M.O, \& Preston, C.D. 2014. Atlas of British and Irish bryophytes. Newbury: Pisces Publications.

Bosanquet, S.D.S. 2012. Baltic Bryum Bryum marratii in south Wales. Unpublished report, Natural Resources Wales.

Bosanquet, S.D.S. 2013. Dune slack bryophytes at Pembrey/Tywyn Burrows. Unpublished report, Natural Resources Wales.

Bosanquet, S.D.S \& Dines, T. 2011. A Bryophyte Red Data List for Wales. Salisbury: Plantlife.

Callaghan, D.A. 2017. Bryophyte survey and assessment of Morfa Harlech NNR. Unpublished report to Natural Resources Wales.

Flowers, T.J., Galal, H.K. \& Bromham, L. 2010. Evolution of halophytes: multiple origins of salt tolerance in land plants. Functional Plant Biology, 37: 604-612.

Garbary, D.J., Miller, A.G., Scrosati, R., Kim, K-Y. \& Schofield, W.B. 2008. Distribution and salinity tolerance of intertidal mosses from Nova Scotian salt marshes. Bryologist 111: 282-291.

Hill, M.O., Blackstock, T.H., Long, D.G. \& Rothero, G.P. 2008. A checklist and census catalogue of British and Irish bryophytes. Cardiff: The British Bryological Society.

Hill, M.O., Preston, C.D., Bosanquet, S.D.S. \& Roy, D.B. 2007. BRYOATT: attributes of British and Irish mosses, liverworts and hornworts. Cambridge: Centre for Ecology and Hydrology.

Hodgetts, N.G. 2011. A revised Red List of bryophytes in Britain. Field Bryology, 103: 40-49.

Hodgetts, N.G. 2015. Checklist and country status of European bryophytes: towards a new Red List for Europe. Irish Wildlife Manuals, No. 84. Dublin: National Parks and Wildlife Service, Department of Arts, Heritage and the Gaeltacht.

Holyoak, D.T. 2015. A survey of rare coastal species of the moss genus Bryum in Wales in September 2015. Unpublished report to Natural Resources Wales.

Lockhart, N., Hodgetts, N.G. and Holyoak, D.T. 2012. Rare and threatened bryophytes of Ireland. Bangor: National Museums Northern Ireland. 
Lowe, J.A., Howard, T.P., Pardaens, A., Tinker, J., Holt, J., Wakelin, S., Milne, G., Leake, J., Wolf, J., Horsburgh, K., Reeder, T., Jenkins, G., Ridley, J., Dye, S. \& Bradley, S. 2009. UK Climate Projections science report: marine and coastal projections. Exeter: Met Office Hadley Centre.

Pescott, O. 2016. Revised lists of nationally rare and scarce bryophytes for Britain. Field Bryology, 115: 22-30.

Quantum GIS Development Team. 2017. Quantum GIS Geographic Information System. Open Source Geospatial Foundation Project. http://qgis.osgeo.org

R Core Team. 2017. R: a language and environment for statistical computing. Vienna: R Foundation for Statistical Computing.

Smith, A.J.E. 2004. The moss flora of Britain and Ireland. Second edition. Cambridge: Cambridge University Press.

Šoltés, R., Nižňanská, M. and Chromý, P. 2010. The halophyte moss species Bryum marratii Wilson in Slovakia. Thaiszia, 20: 105-108.

Stratford, C.J., Robins, N.S., Clarke, D., Jones, L. and Weaver, G. 2013. An ecohydrological review of dune slacks on the west coast of England and Wales. Ecohydrology, 6: 162-171.

Tyler, R.H., Boyer, T.P., Minami, T., Zweng, M.M. and Reagan, J.R. 2017. Electrical conductivity of the global ocean. Earth, Planets and Space, 69: 156.

Zechmeister, H.G. 2005. Bryophytes of continental salt meadows in Austria. Journal of Bryology, 27: 297-302. 


\section{Appendix 1. Location coordinates of Bryum marratii colonies}

Data for each location presented as ‘easting, northing (horizontal accuracy), altitude (vertical accuracy)’, with horizontal measures as Ordnance Survey National Grid reference system and vertical measures as m a.s.l. Horizontal and vertical accuracies are derived by the Leica Viva GS14 GPS unit, such that there is at least a two third probability that the computed position deviates from the true position by less than the value indicated.

Pembrey: 238447.53, 204635.99 (0.0082), 4.7451 (0.0111); 238448.48, 204635.35 (0.008), 4.755 (0.0114); 238449.64, 204634.46 (0.0106), 4.6559 (0.0161); 238449.92, 204636.46 (0.0099), 4.7512 (0.0142); 238449.94, 204636.63 (0.0097), 4.6588 (0.0141); 238450.48, 204634.12 (0.0114), 4.7566 (0.0189); 238451.95, 204635.23 (0.0088), 4.6624 (0.0134); 238452.23, 204635.77 (0.009), 4.7547 (0.0149); 238452.73, 204644.13 (0.0081), 4.6876 (0.0121); 238452.82 , 204635.62 (0.0086), 4.6492 (0.0138); 238452.82, 204644.4 (0.0069), 4.687 (0.0102); 238457.11, 204636.23 (0.0084), 4.7438 (0.0117); 238457.13, 204636.2 (0.0084), 4.7619 (0.0129); 238461.44, 204640.24 (0.0074), 4.7247 (0.0105); 238461.45, 204639.89 (0.0085), 4.7411 (0.012); 238462.73, 204640.7 (0.0069), 4.7614 (0.0101); 238462.81, 204640.28 (0.0077), 4.7294 (0.0112); 238462.89, 204640.31 (0.0081), 4.7296 (0.0116); 238462.94, 204640.13 (0.0079), 4.7497 (0.0114); 238492.01, 204602.57 (0.0061), 4.7737 (0.0114); 238495.88, 204613.05 (0.0067), 4.6997 (0.0125); 238495.95, 204613 (0.0082), 4.727 (0.0151); 238496.34, 204608.89 (0.0065), 4.7598 (0.0119); 238496.54, 204613.18 (0.007), 4.7042 (0.0133); 238506.91, 204617.2 (0.0057), 4.732 (0.0105); 238507.02, 204616.84 (0.0061), 4.6708 (0.0111); 238515.19, 204607.03 (0.0063), 4.7894 (0.0114); 238515.28, 204606.77 (0.0059), 4.8443 (0.0108); 238515.48, 204607.25 (0.0056), 4.7797 (0.0103); 238515.82, 204607.11 (0.0058), 4.7566 (0.0105); 238515.91, 204607.04 (0.0058), 4.7652 (0.0106); 238523.67, 204607.6 (0.0067), 4.7582 (0.0118); 238540.81, 204613.53 (0.0064), 4.7455 (0.0115); 238541.08, 204611.99 (0.0108), 4.6683 (0.0196); 238647.62, 204563.41 (0.0073), 4.6247 (0.0101); 238648.58, 204567.91 (0.0078), 4.6138 (0.0119); 238649.65, 204564.03 (0.008), 4.695 (0.0113); 238649.69, 204563.84 (0.0084), 4.68 (0.0121); 238649.72, 204564.03 (0.0074), 4.6647 (0.0103); 238649.86, 204564.39 (0.0083), 4.6406 (0.0114); 238650.31, 204569.07 (0.0088), 4.5796 (0.0137); 238650.31, 204567.62 (0.0092), 4.5642 (0.0145); 238650.39, 204568.29 (0.0076), 4.5685 (0.0116); 238657.82, 204562.51 (0.007), 4.6222 (0.0103); 238658.33, 204562.59 (0.0064), 4.6239 (0.0098); 238658.62, 204562.83 (0.0068), 4.6411 (0.01); 238658.67, 204562.09 (0.0074), 4.7212 (0.0113); 238658.73, 204562.07 (0.0061), 4.6712 (0.0091); 238659.02, 204562.04 (0.0077), 4.6764 (0.0115); 238659.04, 204561.96 (0.0067), 4.6955 (0.01); 238659.05, 204562.14 (0.0072), 4.6846 (0.0107); 238659.14, 204562.29 (0.0069), 4.6153 (0.0102); 238659.2, 204561.97 (0.0061), 4.6793 (0.0095); 238659.28, 204561.92 (0.0059), 4.701 (0.009); 238660.49, 204561.99 (0.0072), 4.7185 (0.0116); 238660.6, 204561.77 (0.0064), 4.6921 (0.0099); 238660.65, 204561.78 (0.0089), 4.6839 (0.0138); 238660.67, 204561.64 (0.0069), 4.7586 (0.0111); 238660.86, 204560.25 (0.0065), 4.6753 (0.0102); 238660.87, 204561.67 (0.0067), 4.758 (0.0109); 238660.92, 204561.64 (0.0072), 4.7323 (0.0112); 238661.73, 204560.5 (0.0066), 4.6169 (0.0102); 238661.76, 204561.39 (0.0087), 4.6897 (0.014); 238661.82, 204560.61 (0.0064), 4.6034 (0.01); 238661.87, 204560.36 (0.0069), 4.6911 (0.0106); 238662.02, 204560.41 (0.0076), 4.7034 (0.0116); 238662.62, 204559.74 (0.0067), 4.6476 (0.0101); 238662.66, 204559.83 (0.0068), 4.6295 (0.0103); 238664.48, 204558.94 (0.007), 4.6584 (0.0108); 238664.66, 204558.66 (0.0074), 4.6131 (0.0116); 238664.91, 204558.4 (0.0076), 4.6512 (0.0117); 238665.73, 204558.2 (0.0069), 4.7243 (0.0111); 238666.69, 204557.96 (0.0074), 4.7136 (0.0116); 238666.75, 204558.12 (0.0076), 4.66 (0.0122); 238666.84, 204557.89 (0.0072), 4.7214 (0.0115); 238667.07, 204556.28 (0.0063), 4.7078 (0.0108). Whiteford: $244437.84,194502.35$ (0.0063), 4.7593 (0.0104); 244437.84, 194503.51 (0.0072), 4.799 (0.014); 244471.71, 194533.39 (0.0067), 4.4177 (0.0107); 244591.42, 194686.59 (0.006), 4.8255 (0.0076); 244598.66, 194698.25 (0.0052), 4.788 (0.0088); 244598.93, 194698.9 (0.0051), 4.7894 (0.0086); 244598.95, 194698.82 (0.0054), 4.8156 (0.0091); 244599.06, 194700.23 (0.0053), 4.8266 (0.0089); 244599.22, 194698.54 (0.0058), 4.7624 (0.0094); 244599.32, 194700.19 (0.0056), 4.8023 (0.0093); 244599.64, 194700.5 (0.005), 4.8008 (0.0083); 244599.72, 194699.82 (0.0058), 4.744 (0.011); 244610.47, 194722.18 (0.0064), 4.769 (0.0083); 244635.79, 194926.84 (0.0075), 4.9866 (0.0107); 244638.16, 194924.09 (0.006), 4.847 (0.012); 244638.18, 194924.27 (0.0102), 4.881 (0.016); 244638.33, 194924.54 (0.0081), 4.8649 (0.0112); 244638.44, 194924.43 (0.0074), 4.8382 (0.0101); 244638.67, 194925.25 (0.008), 4.8237 (0.0115); 244638.9, 194925.35 (0.0231), 4.7688 (0.0318); 244638.94, 194923.24 (0.0069), 4.8283 (0.0094); 244638.96, 194923.15 (0.0073), 4.7745 (0.01); 244642.39, 194929.41 (0.0078), 4.7567 (0.0106); 244643.25, 194929.65 (0.0066), 4.7598 (0.0091); 244643.51, 194929.62 (0.0072), 4.7719 (0.0099); 244686.69, 194951.06 (0.01), 4.7096 (0.0179); 244692.73, 194960.9 (0.0082), 4.6753 (0.0115); 244701.5, 194977.04 (0.0076), 4.7029 (0.0123); 244701.67, 194976.53 (0.0089), 4.7196 (0.0154); 244702.42, 194986.33 (0.0079), 4.8104 (0.0114); 244702.8, 194979.07 (0.0074), 4.6815 (0.0113); 244702.98, 194978.69 (0.0076), 4.6935 (0.0116); 244703.09, 194978.46 (0.062), 4.69 (0.013); 244703.38, 194985.42 (0.0078), 4.785 (0.0119); 244703.6, 194977.68 (0.0065), 4.6269 (0.0098); 244728.81, 195046.47 (0.0053), 4.7754 (0.009); 244728.86, 195046.44 (0.0067), 4.7719 (0.0113); 244728.91, 195046.52 (0.0062), 4.7715 (0.0105); 244729.25, 195046.45 (0.0054), 4.7579 (0.009); $244729.39,195046.39$ (0.0059), 4.7796 (0.0099); 244729.5, 195046.39 (0.0054), 4.7609 (0.0091); 244729.75, 195046.47 (0.0059), 4.7674 (0.0102); 244731.77, 195046.45 (0.0066), 4.728 (0.013); 244731.84, 195045.89 (0.0056), 4.7175 (0.0093). 
Table 1. Tidal inundation of Bryum marratii colonies.

\begin{tabular}{|c|c|c|c|c|c|c|}
\hline \multirow[t]{2}{*}{ Colony height } & \multirow{2}{*}{$\begin{array}{c}\text { Inundation } \\
\text { frequency } \\
\text { (inundation }^{-1} \mathrm{yr}^{-1} \text { ) }\end{array}$} & \multicolumn{2}{|c|}{$\begin{array}{l}\text { Length of each } \\
\text { inundation (hr) }\end{array}$} & \multicolumn{2}{|c|}{$\begin{array}{l}\text { Depth of each } \\
\text { inundation }(\mathrm{cm})\end{array}$} & \multirow{2}{*}{$\begin{array}{c}\text { Total } \\
\text { inundation time } \\
\left(\text { day }^{-1} \mathbf{y r}^{-1}\right)\end{array}$} \\
\hline & & Mean & Max. & Mean & Max. & \\
\hline Lowest (4.42 maOD) & 128 & 1.52 & 3.25 & 37.5 & 131.2 & 8.1 \\
\hline Average (4.72 maOD) & 69 & 1.26 & 2.75 & 27.0 & 100.8 & 3.6 \\
\hline Highest (4.99 maOD) & 32 & 0.99 & 2.25 & 18.3 & 74.3 & 1.3 \\
\hline
\end{tabular}




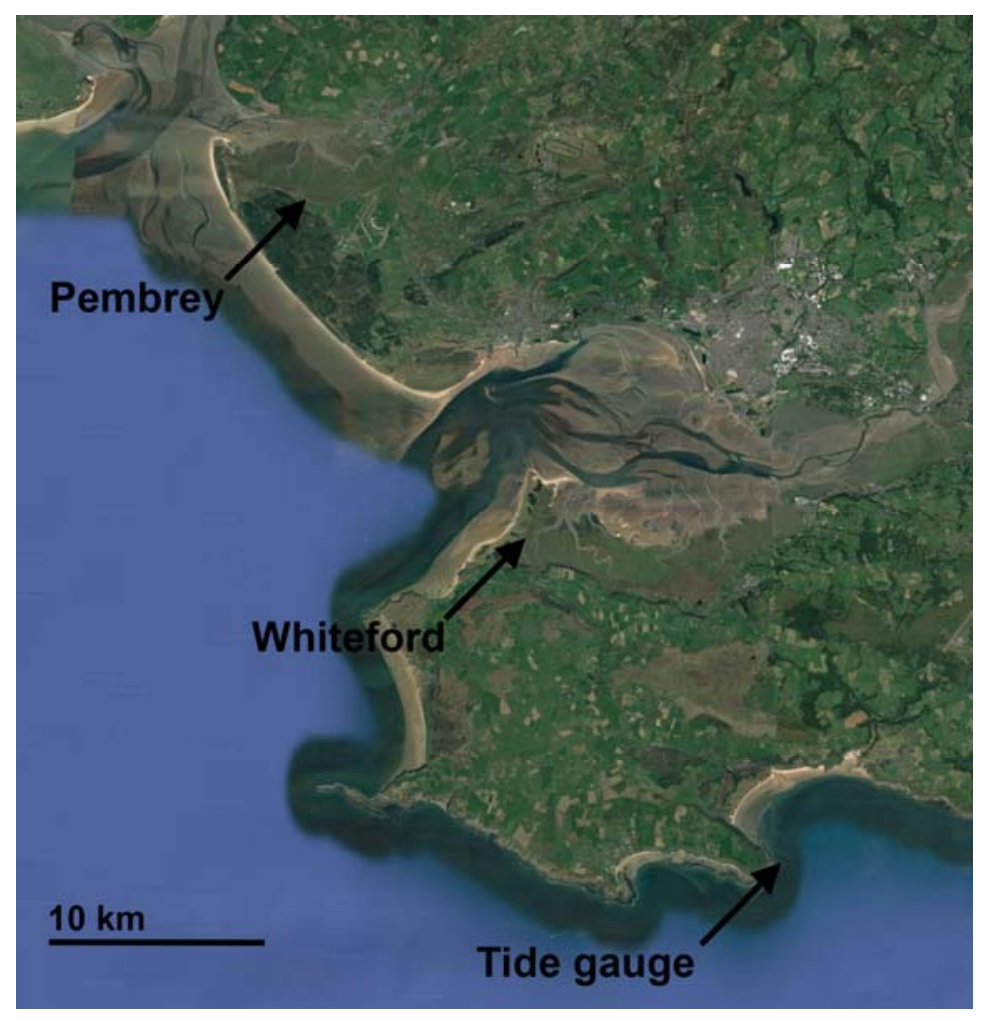

Figure 1. Location of study sites. Satellite image (c) 2017 Google, DigitalGlobe. 


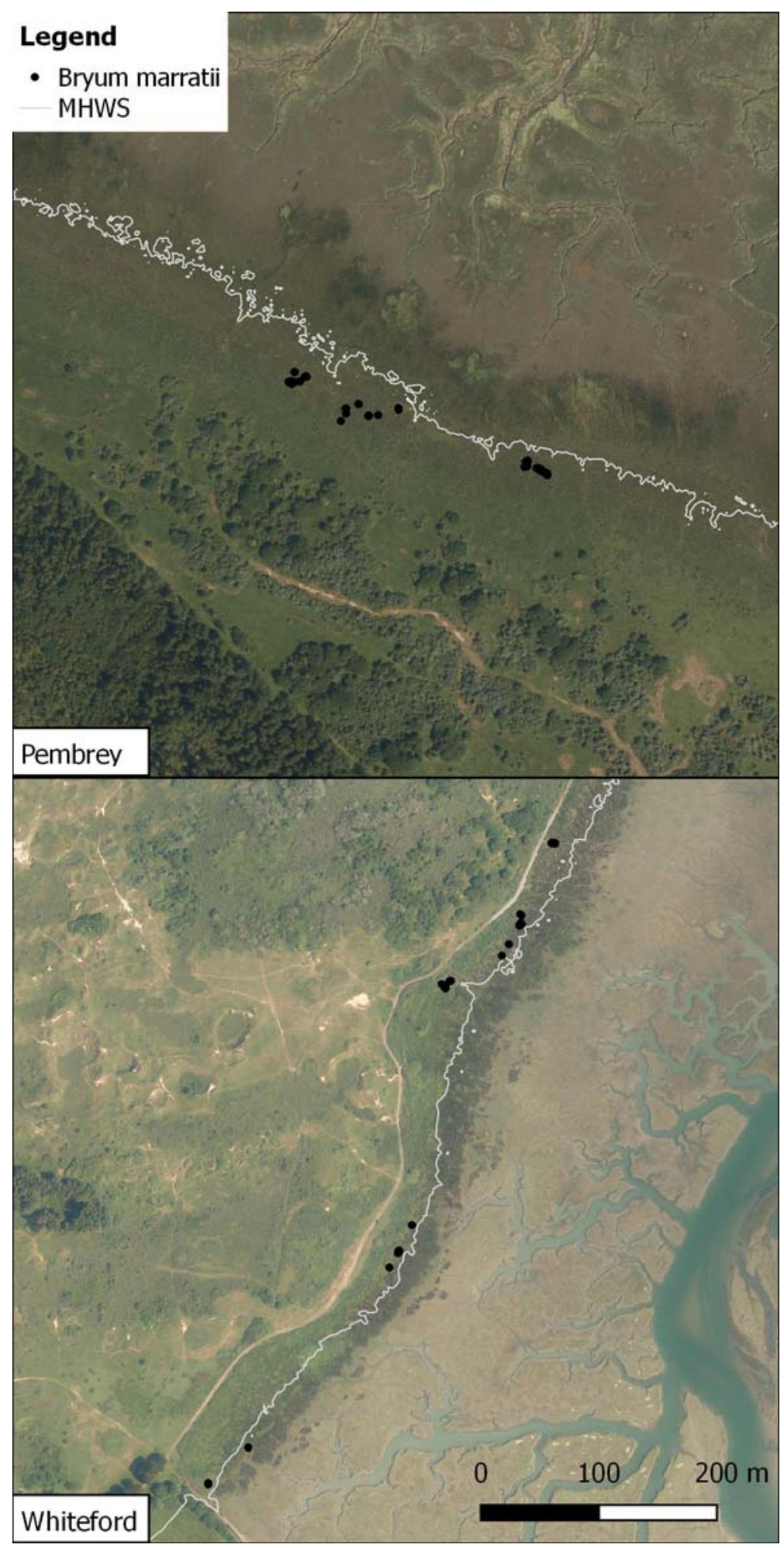

Figure 2. Distribution of Bryum marratii colonies. The predicted Mean High Water Spring tide for 2008-2016 (4.54 maOD) is indicated, obtained from The National Tidal and Sea Level Facility, The National Oceanography Centre (NOC). Satellite image (c) 2017 Google, DigitalGlobe. 


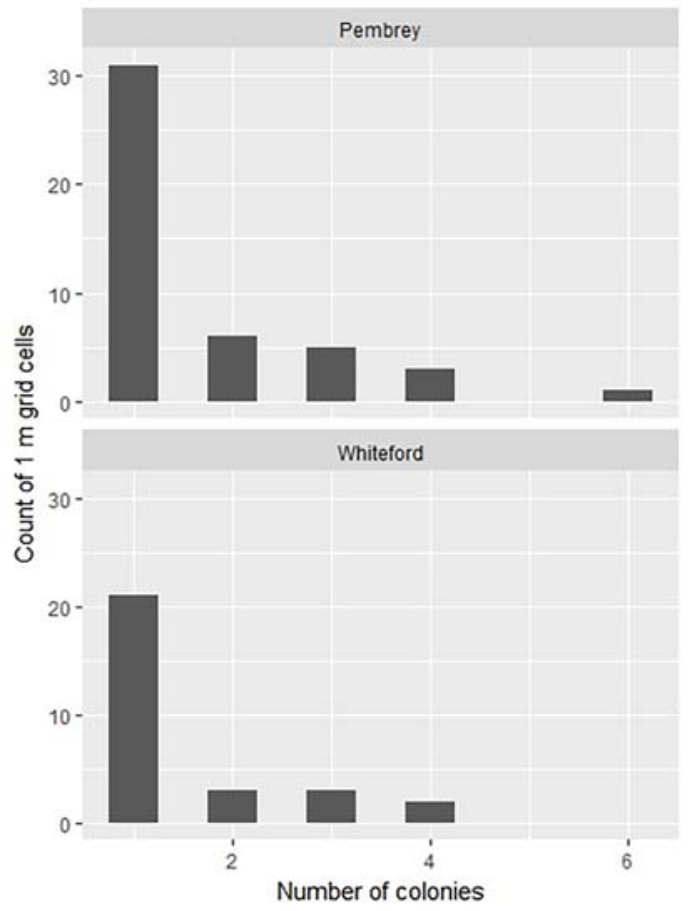

Figure 3. Frequency distribution of counts of Bryum marratii colonies within OS 1 x $1 \mathrm{~m}$ grid cells.

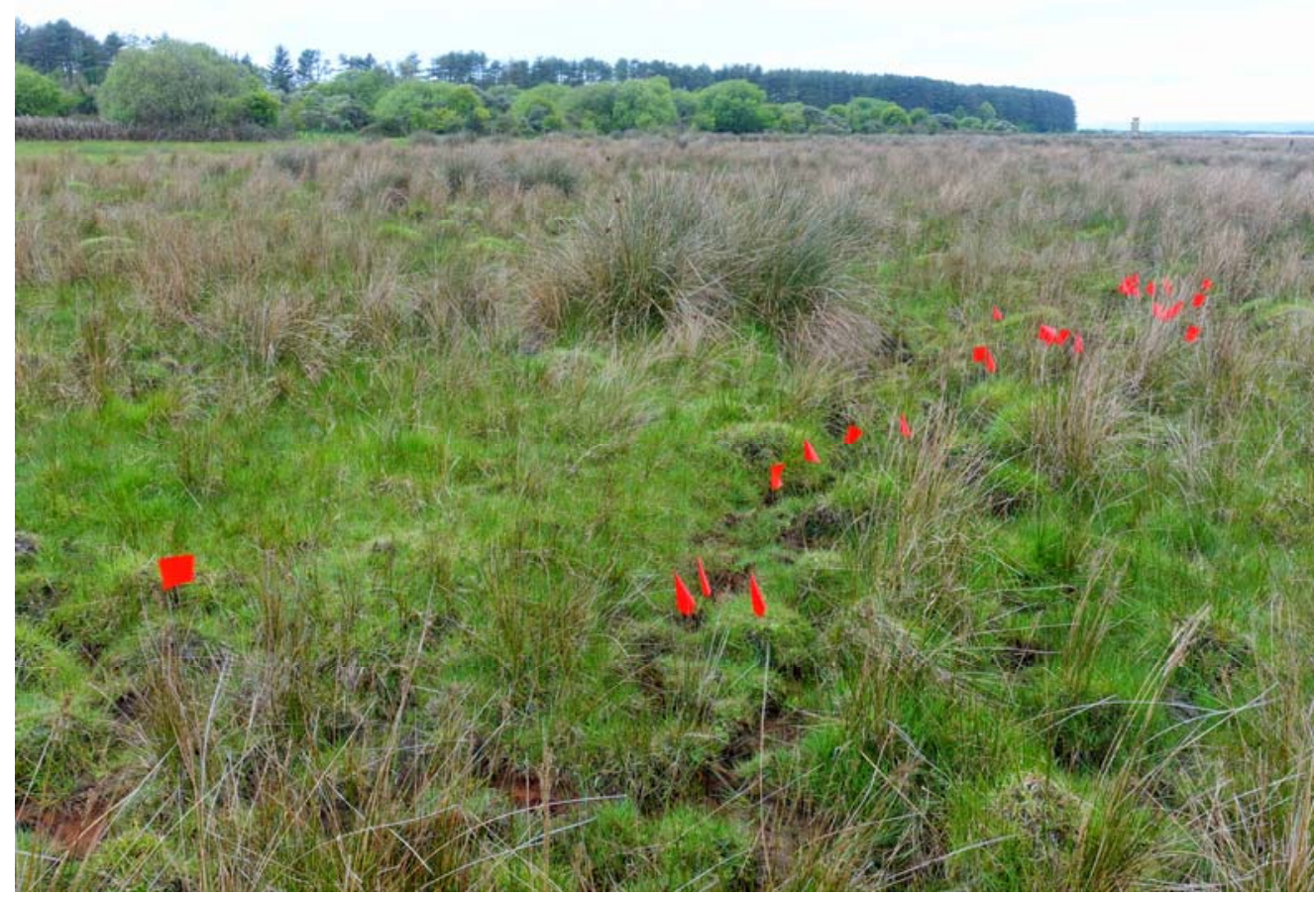

Figure 4. Flagged Bryum marratii at the largest cluster of colonies, on upper saltmarsh at Pembrey. Photo: D.A. Callaghan. 


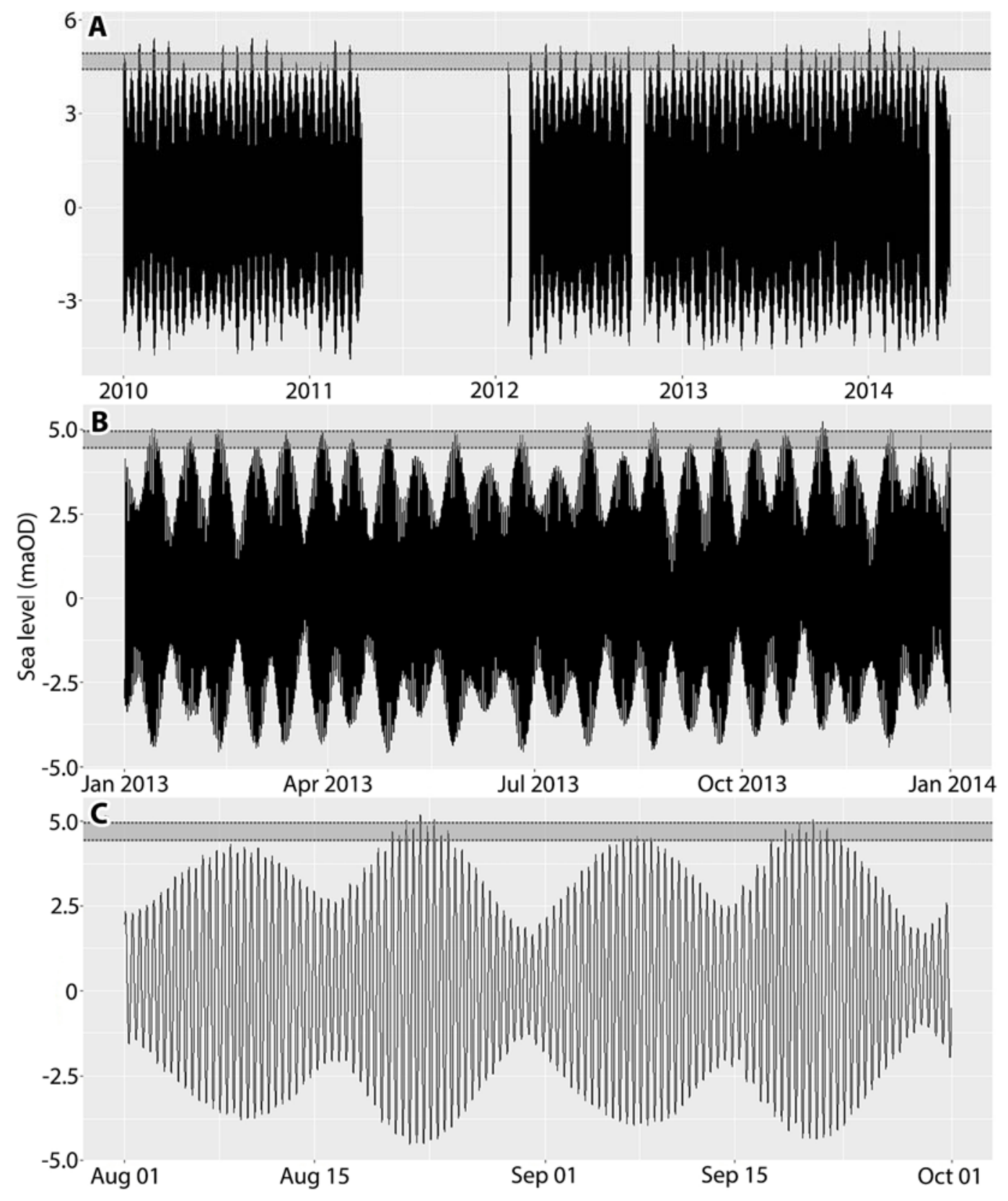

Figure 5. Elevation zone of Bryum marratii (grey band) and tide levels during (A) January 2010 to June 2014, (B) January to December 2013 and (C) August to September 2013. Tide level values considered ‘improbable’ by BODC are omitted. 